\title{
20. On the Chemistry of Heparin
}

\author{
By Erik Jorpes, From the Chemistry Department of the Karolinska Institutet, \\ Stockholm, Sweden
}

(Received 21 January 1942)

\section{The molecular structure of heparin}

Howell's observation [1928] that heparin contains a uronic acid was confirmed by Jorpes $[1935,1,2]$, who also found an amino-sugar and a high content of ester sulphates. On the basis of quantitative analyses, Jorpes concluded that heparin is a polysulphuric ester of chondroitin or of some closely related substance. When the amino-sugar was identified as glucosamine [Jorpes \& Bergström, 1936], it became evident that the structural carbohydrate unit of heparin was mucoitin, if the uronic acid is assumed to be glucuronic acid. These findings were confirmed by Meyer [1938]. It is now generally agreed that heparin belongs to the same group of substances as chondroitin sulphuric acid [Reinert \& Winterstein, 1939; Charles \& Todd, 1940].

It is almost certain that the amino group is acetylated as is the case in all the other natural compounds, chitin, chondroitin sulphuric acid and the immune carbohydrates which contain an amino-sugar. The shape of the titration curve in the range $p \mathrm{H} 7-10$ also clearly indicates that the amino group is not free [Wilander, 1938]. There was only a trace of buffering capacity in this range, whereas with chondrosin, where the amino group is free, there was a distinct rise of the curve. At least $50 \%$ of the theoretical amount of acetic acid has been isolated and identified as silver salt [Jorpes \& Bergström, 1937].

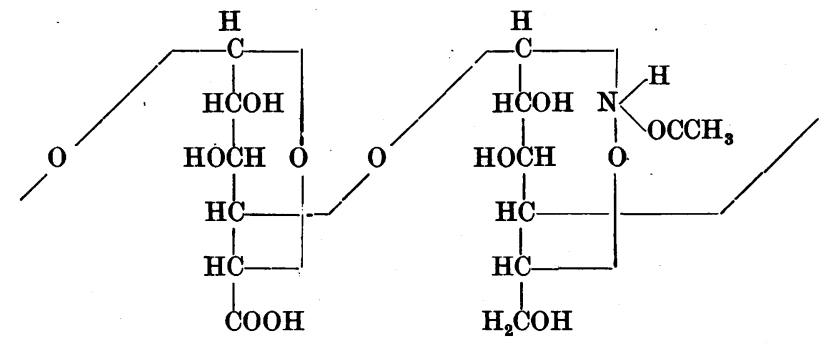

The probable disaccharide unit of heparin.

If the assumption is made that the disaccharide unit has an internal structure similar to that of the ordinary disaccharides, there are four hydroxyl groups which could be esterified with sulphuric acid. Consequently the following compounds would have to be considered.

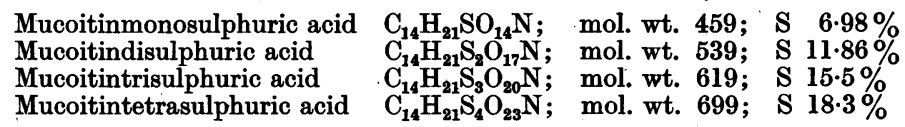

The $\mathrm{Na}$ and $\mathrm{Ba}$ salts would have the following composition.

The Na salt of the:

Monosulphuric acid

Disulphuric acid

Trisulphuric acid

Tetrasulphuric acid

The Ba salt of the:

Disulphuric acid

Trisulphuric acid
$\mathrm{C}_{14} \mathrm{H}_{19} \mathrm{SO}_{14} \mathrm{NNa}_{2} ; \quad$ mol. wt. $503 ; \mathrm{S} \quad 6.36 \%$

$\mathrm{C}_{14} \mathrm{H}_{18} \mathrm{~S}_{2} \mathrm{O}_{17} \mathrm{NNa}_{3}$; mol. wt. $605 ; \mathrm{S} 10.58 \%$

$\mathrm{C}_{14} \mathrm{H}_{17} \mathrm{~S}_{3} \mathrm{O}_{20} \mathrm{NNa}_{4} ;$ mol. wt. 707; $\mathrm{S} 13.58 \%$

$\mathrm{C}_{14} \mathrm{H}_{16} \mathrm{~S}_{4} \mathrm{O}_{23} \mathrm{NNa}_{5}$; mol. wt. $809 ; \quad \mathrm{S} 15 \cdot 81 \%$

$$
\begin{aligned}
& \left(\mathrm{C}_{14} \mathrm{H}_{18} \mathrm{~S}_{2} \mathrm{O}_{17} \mathrm{~N}\right)_{2} \mathrm{Ba}_{3} ; \mathrm{S} \quad 8 \cdot 62 \% \\
& \mathrm{C}_{14} \mathrm{H}_{17} \mathrm{~S}_{3} \mathrm{O}_{20} \mathrm{NBa}_{2} \text {; } \mathrm{S} 10 \cdot 80 \% \\
& \text { ( } 203 \text { ) }
\end{aligned}
$$


As early as 1935, fractions were isolated [Jorpes, 1935, 2] with a sulphur content corresponding very closely to that of a chondroitin or mucoitin trisulphuric acid. As the pure protein-free heparin had a lower sulphur content it was assumed to be a mixture of the different sulphuric esters, mainly di- and tri-sulphuric acids. It could not be proved, however, that a tetrasulphuric acid is also present in the natural heparin.

\section{Crystalline heparin}

In the meantime, the concept of a homogeneous crystalline heparin has been introduced. Crystalline heparin has been the subject of much discussion. Fischer \& Schmitz [1933] thought that they had obtained a crystalline brucine salt of heparin. In the same year, Charles \& Scott [1933] reported on a semi-crystalline preparation. Finally, in 1936, these authors [Charles \& Scott, 1936] isolated a Ba salt of lung heparin, which they considered to be crystalline and which, since then, has been treated in the literature as the pure crystalline anticoagulant. Unfortunately, their preparation contained only $11.5 \% \mathrm{~S}$ in the free acid, or $20 \%$ less than the $S$ content of the free acid of an amorphous liver heparin isolated from the insoluble brucine salt and first described by the present author in 1935. This 'crystalline' Ba salt of liver and lung heparin was studied by Charles \& Todd [1940] and claimed by them to be a homogeneous compound, probably identical with the preparation described by Reinert \& Winterstein [1939]. Both groups of authors were, in fact, still of the opinion that the compound contained $2 \frac{1}{2} \mathrm{~S}$ atoms to each mucoitin unit.

The compound of Charles \& Todd seemed to be crystalline. There was, however, no convincing evidence to justify the assumption of a crystalline structure. The crystals were 'too small and heavily twinned for the X-ray diagram'. Further information would also have been desirable regarding the $S$ content and the optical rotation of their preparations. The $\mathrm{S}$ content of the Ba salt was $9 \cdot 6 \%$ and of the $\mathrm{NH}_{4}$ salt $12 \cdot 2 \%$. Both preparations were dried at room temperature and no information was given as to their water content. Compared with a $\mathrm{Na}$ salt described in this paper containing $13.8 \% \mathrm{~S}$, the $\mathrm{NH}_{4}$ salt ought to contain about $11 \%$ moisture. An analysis of the optical rotation would have been desirable. Thus, the preparation of Reinert \& Winterstein, which was claimed by them to be derived from the 'crystalline' Ba salt, had a rotation of $+42^{\circ}$, a figure which is very much lower than the rotation $+63^{\circ}\left(+66^{\circ}\right.$ ?) of the strongest heparin preparations. Charles \& Todd, in discussing their results, assumed that the pure heparin contains $2 \frac{1}{2}$ sulphate groups to each mucoitin unit. Their conclusions were based on the $S: N$ ratio. These acidic polysaccharides, however, are never completely free from traces of proteins or ammonium salts. The $\mathrm{N}$ content, therefore, does not correspond to the content of hexosamine.

As to the product described in 1939 as pure 'crystalline' heparin by Reinert \& Winterstein of the Hoffman-La Roche laboratory, it is evident that it was no.more than a mixture of the different polysulphuric esters described above. The $\mathrm{Na}$ salt, recovered from the 'crystalline' Ba salt, contained $11.1 \% \mathrm{~S}$ in the air-dry substance $(11.9 \%$ of the dry substance), and showed an optical activity of $+42^{\circ}$. Consequently it corresponds to the purified heparin which was used by the present author as starting material for the fractionation of the brucine salts of heparin. From this material the mucoitin di- and tri-sulphuric acids were isolated. Although the present author found that the material contained at least one fraction with $12.5 \% \mathrm{~S}$ in the $\mathrm{Na}$ salt, and a composition very similar to that of a mucoitin trisulphuric acid, Reinert \& Winterstein assumed, in agreement with Charles \& Todd, that there were $2 \frac{1}{2} \mathrm{~S}$ atoms to each hexosamine residue in their preparation. Further, the findings of Jorpes \& Bergström [1937], that these strong heparin preparations with more than $12 \% \mathrm{~S}$ may have a specific rotation of $+66^{\circ}$, seemed also to have escaped the attention of these authors. The low $\mathrm{S}$ content and the low specific 
rotation of the heparin samples of Reinert \& Winterstein prove that these samples consisted of pure heparin but were by no means crystalline homogeneous compounds. The anticoagulant activity also corresponds to this. A sample of the commercial Liquaemin Roche, which was claimed to be prepared from 'crystalline salts', and which was analysed by the author in September 1940, was found to have the same strength (100\%) as our standard powder, whereas the trisulphuric acid has an activity of 140-150\%. All these facts clearly indicate that the product of Reinert \& Winterstein was not a crystalline compound but a mixture of the different fractions isolated and separated from each other as far-back as 1935. It must be admitted therefore that the discussion of crystalline heparin so far has rested on an insecure foundation.

In two later reports, crystalline heparin has been discussed. Thus, Jaques \& Waters [1940] reported on a crystalline $\mathrm{Ba}$ salt isolated from the blood of dogs in anaphylactic shock which appeared to be homogeneous. Furthermore, Jaques $[1940,1]$ reported on crystalline $\mathrm{Ba}$ salts of heparin, isolated from the lungs of different animals, all of which had a similar composition. The water-free $\mathrm{Ba}$ salts of these heparins contained the following amounts of $S$, viz. dog heparin $10 \cdot 8$, that from the cow $10 \cdot 8$, from the pig $10 \cdot 4$, and from the sheep $11 \cdot 6 \%$. No further chemical details were given. Evidently, the $S$ content of these preparations corresponds exactly with that of the Ba salt of the mucoitin trisulphuric acid discussed above (calculated at $10.8 \% \mathrm{~S}$ ). Furthermore, if the figure given for the $S$ content of sheep heparin is correct $(11 \cdot 6 \%)$, it would indicate the presence of a certain amount of the tetrasulphuric acid of mucoitin.

In this last paper the very interesting observation was made that heparins from different animals, in spite of their similarity in chemical composition, showed individual biological activities as tested in a coagulation system, the dog heparin being $2 \cdot 4$ times stronger than the ox heparin, and the pig heparin having only $44 \%$ of the strength of the latter. The sheep heparin was still weaker.

\section{Is heparin activity due to one definite homogeneous chemical compound only?}

There is one discrepancy which is very remarkable between the findings of the present author and the statements made in the literature. The strongest heparin fractions, the chemical composition of which corresponds to that of 'crystalline' heparin, make up only a small part of the heparin preparations, e.g. usually $15-20 \%$ in ox-liver heparin and a still smaller percentage in heparin from lungs and spleen. If the heparin is very little influenced by the procedure of preparation, the main part of the natural heparin must have a lower $S$ content and a weaker anticoagulant activity than the strongest fractions separated from it as $\mathrm{Ba}$ or brucine salts. Consequently, these fractions alone, even if they were crystalline, cannot be claimed to be the natural heparin, because the main part thereof consists of a polysaccharide of a much lower degree of esterification. The question arises whether these. weaker fractions occur in the body or if they are solely decomposition products.

For the elucidation of this question I have analysed heparin from different organs and from different species of animals qualitatively and quantitatively. The fate of heparin during the course of its preparation has been followed. Furthermore, the fractionation with brucine has been once more studied in detail. The decreasing solubility of the brucine salts which parallels the increasing $S$ content, offers an excellent means of studying the crude polysaccharide of heparin. The only way of obtaining the brucine salts is, of course, by means of electrodialysis.

\section{Heparin from ox spleen}

$200 \mathrm{~kg}$. of ox spleen were worked up in the usual way. The protein-free polysaccharide fraction, $4.6 \mathrm{~g}$., was dialysed in a cellophane sac against distilled water. The substance dialysing out, had only $4 \%$ of the standard heparin activity. The heparin inside the sac 
was precipitated with alcohol in the presence of sodium chloride. The yield was $3 \cdot 3 \mathrm{~g}$. airdry substance with $9 \cdot 12 \%$ moisture and $45-50 \%$ heparin activity. The water-free substance analysed as follows: ash $29 \cdot 8 ; \mathrm{N} 2 \cdot 83 ; \mathrm{S} 9 \cdot 35$; hexosamine $22 \%$. ' $[\alpha]_{D}^{20^{\circ}}=+29^{\circ}$.

Fractionation by means of the brucine salt. $2 \cdot 69 \mathrm{~g}$. of the dry substance were electrodialysed for $2 \frac{1}{2} \mathrm{hr}$. The substance removed with the neutralized anodic fluid, $0.54 \mathrm{~g}$., showed a S content of $2.7 \%$ and only $7 \%$ of the standard heparin activity. The inner cell contained, as found after neutralization of a small sample, $2 \cdot 4 \mathrm{~g}$. substance with $9 \cdot 17 \% \mathrm{~S}$ in the $\mathrm{Na}$ salt and a heparin activity of $50-55 \%$. The different $\mathrm{Na}$ salts obtained after fractionating the brucine salts in water, analysed as shown in Table 1.

Table 1. Na salts of heparin from ox spleen as recovered from the different fractions of brucine salts

\begin{tabular}{|c|c|c|c|c|c|}
\hline $\begin{array}{l}\text { Substance recovered } \\
\text { from }\end{array}$ & $\begin{array}{l}\text { Air-dry } \\
\text { substance } \\
\text { g. }\end{array}$ & $\begin{array}{l}\text { Moisture } \\
\%\end{array}$ & $\begin{array}{l}\text { S \% of dry } \\
\text { substance }\end{array}$ & $\begin{array}{c}{[\alpha]_{D}^{20^{\circ}}} \\
\text { (dry substance) }\end{array}$ & $\begin{array}{l}\text { Heparin activity of } \\
\text { air-dry substance, } \\
\% \text { of standard }\end{array}$ \\
\hline $\begin{array}{c}\text { Mother liquor: } 1 \text { lst } \\
\text { 2nd } \\
\text { 3rd } \\
\text { Insoluble brucine salt }\end{array}$ & $\begin{array}{l}1 \cdot 000 \\
0 \cdot 255 \\
0 \cdot 028 \\
0.038\end{array}$ & $\begin{array}{l}17 \cdot 3 \\
12 \cdot 6 \\
13 \cdot 4 \\
13 \cdot 2\end{array}$ & $\begin{array}{r}8 \cdot 3 \\
10 \cdot 3 \\
12 \cdot 6 \\
13 \cdot 9\end{array}$ & $\begin{array}{l}+\mathbf{2 6 ^ { \circ }} \\
+\mathbf{3 3 ^ { \circ }} \\
+\mathbf{3 9 \cdot 4 ^ { \circ }} \\
+\mathbf{5 0} 0^{\circ}\end{array}$ & $\begin{array}{l}40 \\
60 \\
100(?) \\
100\end{array}$ \\
\hline
\end{tabular}

\section{Heparin from lungs of cattle}

$500 \mathrm{~kg}$. of ox lungs yielded $20 \cdot 8 \mathrm{~g}$. of air-dry substance after dialysis of the $\mathrm{Na}$ salt initially obtained (23 g.). Moisture $7 \cdot 98 \%$. Anticoagulant activity of the air-dry substance, $50 \%$. The dry substance analysed as follows: ash $38 \cdot 7 ; \mathrm{N} 2.9 ; \mathrm{S} 10 \cdot 62$; hexosamine $24.9 \%$. $[\alpha]_{D}^{20^{\circ}}=+38 \cdot 7^{\circ}$.

Fractionation by means of the brucine salt. $9 \cdot 2$ g. dry substance were electrodialysed in $350 \mathrm{ml}$. of water for $8 \mathrm{hr}$. The anode liquor contained $2 \mathrm{~g}$. of dry substance with $8.7 \%$ $\mathrm{S}$ and a heparin activity of $35 \%$. The inner cell contained $7 \cdot 8 \mathrm{~g}$. of heparin calculated as dry $\mathrm{Na}$ salt with $\mathbf{9 \cdot 7 5} \% \mathrm{~S}$ and $60 \%$ heparin activity. The original strength of the air-dry substance which was electrodialysed was $50 \% \cdot[\alpha]_{D}^{20^{\circ}}=+41^{\circ}$. The results of the analysis of the $\mathrm{Na}$ salts obtained after fractionation of the brucine salts are given in Table 2 .

Table 2. Na salts of heparin from the lungs, recovered from the different fractions of brucine salts

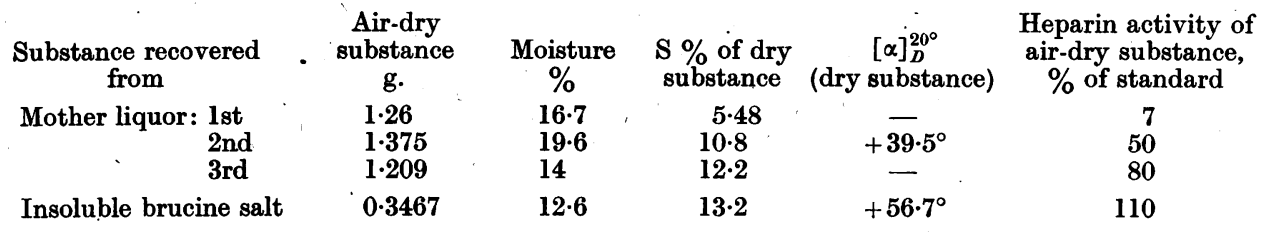

\section{Heparin from ox liver}

Fractionation by means of brucine. - A Na salt of commercial heparin was dialysed for $24 \mathrm{hr}$. in a cellophane sac against distilled water in order to remove free sulphates. $4 \cdot 1 \mathrm{~g}$. dry substance containing $11 \cdot 1 \% \mathrm{~S}$ and having a heparin activity of $110 \%$ of the standard were dissolved in $150 \mathrm{ml}$. of water and electrodialysed. After $6 \frac{1}{2} \mathrm{hr}$. no alkali was present in the water passing the cathode chamber.

The heparin activity still present in the inner cell after electrodialysis was $75-80 \%$ of the original. Anticoagulant activity, corresponding to the loss, was found in the anode fluid. The water $(10$ l.) which had washed the anode during electrodialysis was collected, neutralized and concentrated in vacuo to $101 \mathrm{ml}$. It contained $0.723 \mathrm{~g}$. of dry substance with the heparin activity unimpaired $(110 \%)$ and with $11.3 \% \mathrm{~S}$. Thus, about $18 \%$ of the 
heparin originally present had passed the anodic parchment membrane without any loss of heparin activity or of sulphur.

No sulphuric acid had been split off from the heparin inside the cell, because two $5 \mathrm{ml}$. samples of the concentrated anode fluid did not contain any free sulphates precipitable with $\mathrm{BaCl}_{2}$ in $0.5 \mathrm{~N} \mathrm{HCl}$.

As to the chemical structure and the anticoagulant activity of the heparin, the electrodialysis of this experiment proved to be quite harmless. Apparently the free acid is stable at room temperature in aqueous solution, at least for a certain time. A similar finding was made in determining the amount of free sulphates in the heparin preparations. In $0 \cdot 5-0 \cdot 75 \mathrm{~N} \mathrm{HCl} \mathrm{no} \mathrm{sulphuric} \mathrm{acid} \mathrm{was} \mathrm{split} \mathrm{off} \mathrm{from} \mathrm{the} \mathrm{heparin} \mathrm{during} 24-48 \mathrm{hr}$. at room temperature.

In another experiment, $9 \cdot 2 \mathrm{~g}$. of the same heparin were electrodialysed in $150 \mathrm{mi}$. of water for $7 \mathrm{hr}$. The heparin activity inside the cell was $80 \%$ of the original. The anode fluid, about 10 l., was neutralized and concentrated in vacuo to $200 \mathrm{ml}$. It contained $1.143 \mathrm{~g}$. of dry substance (12.5\%) with $8.5 \% \mathrm{~S}$ and an anticoagulant activity of $70 \%$. In $10 \mathrm{ml}$. of this solution there was only a trace of sulphate precipitable with $\mathrm{BaCl}_{2}$ in acid solution; consequently only a trace of sulphate had been set free from the heparin during the electrodialysis.

In a further experiment with $10 \mathrm{~g}$. of heparin; $1.8 \%$ of the $\mathrm{S}$ was split off during electrodialysis and recovered from the anode liquor as free sulphates.

6 and $10 \mathrm{~g}$. dry $\mathrm{Na}$ salt of heparin (dialysed) were electrodialysed in two ruins of 8 and $11 \mathrm{hr}$. duration. The combined anode fluids were collected, neutralized and concentrated to a small volume. They contained free sulphates corresponding to $3.5 \%$ and ester sulphates corresponding to $16 \%$ of the total S present in the heparin which had been submitted to electrodialysis. The combined inner fluids were neutralized with brucine and the brucine salts fractionated in water as usual. The brucine was this time removed with a saturated solution of calcium hydroxide at room temperature. The Ca salts were twice reprecipitated with only 1 vol. of alcohol from an almost neutral or faintly alkaline solution; the results are given in Table 3.

\section{Table 3. The Ca salts recovered on removal of brucine from the different fractions of brucine salts}

\begin{tabular}{|c|c|c|c|c|c|c|c|}
\hline \multirow{2}{*}{$\begin{array}{l}\text { Substance recovered } \\
\text { from }\end{array}$} & \multirow{2}{*}{$\begin{array}{c}\text { Air-dry } \\
\text { substance } \\
\text { g. }\end{array}$} & \multirow{2}{*}{$\begin{array}{c}\text { Moisture } \\
100^{\circ} \text { in vacuo } \\
\text { over } \mathrm{P}_{2} \mathrm{O}_{5} \\
\%\end{array}$} & \multicolumn{3}{|c|}{$\%$ of dry substance } & \multirow{2}{*}{$\begin{array}{l}{[\alpha]_{D}^{20^{\circ}} \text { calc. }} \\
\text { per dry } \\
\text { substance }\end{array}$} & \multirow{2}{*}{$\begin{array}{l}\text { Heparin activity of } \\
\text { air-dry substance, } \\
\% \text { of standard }\end{array}$} \\
\hline & & & Ash & $\mathbf{S}$ & $\mathrm{Ca}$ & & \\
\hline $\begin{aligned} & \text { Mother liquor: } \text { lst } \\
& \text { 2nd } \\
& \text { 3rd } \\
& \text { 4th }\end{aligned}$ & $\begin{array}{l}7 \cdot 20 \\
0 \cdot 75 \\
1 \cdot 60 \\
0 \cdot 60\end{array}$ & $\begin{array}{c}10 \cdot 4 \\
6 \cdot 54 \\
10 \cdot 2 \\
9 \cdot 9\end{array}$ & $\begin{array}{l}29 \cdot 8 \\
29 \cdot 6 \\
30 \cdot 3 \\
36 \cdot 3\end{array}$ & $\begin{array}{r}8 \cdot 80 \\
10 \cdot 80 \\
11 \cdot 20 \\
12 \cdot 00\end{array}$ & $\begin{array}{l}10 \cdot 4 \\
10 \cdot 3 \\
12 \cdot 0\end{array}$ & $\begin{array}{l}+45 \cdot 7^{\circ} \\
+45 \cdot 4^{\circ} \\
+57 \cdot 2^{\circ} \\
+61 \cdot 8^{\circ}\end{array}$ & $\begin{array}{r}65 \\
100 \\
100 \\
125\end{array}$ \\
\hline Insoluble brucine salt & $2 \cdot 00$ & $10 \cdot 6$ & $33 \cdot 9$ & $12 \cdot 56$ & $12 \cdot 3$ & $+63 \cdot 5^{\circ} ?$ & $135-140$ \\
\hline
\end{tabular}

The Ca salts recovered (10.92 g.) contained about $80 \%$ of the dry substance and about $70 \%$ of the heparin activity calculated to be found in the inner cell after removal of the heparin which had passed the anode membrane. Evidently no considerable destruction with loss of heparin activity had taken place during electrodialysis, even in this experiment, which revealed a certain loss of ester sulphates $(3.5 \%)$.

In two other experiments samples of the inner fluid were neutralized following electrodialysis for 8 and $10 \mathrm{hr}$. The $\mathrm{Na}$ salts of the inner fluids were carefully assayed against the $\mathrm{Na}$ salt of the starting material.

There had been no detectable loss of anticoagulant activity during electrodialysis; the potency of the samples did not deviate more than $5 \%$ from the strength of the heparin used as starting material. 
As is evident from these experiments, very little sulphuric acid, if any at all, is split off from the heparin during electrodialysis. The various fractions of heparin of different sulphur content, separated from each other as brucine salts, must therefore be assumed to be performed in the protein-free purified heparin. They must occur together before electrodialysis because a considerable part of the heparin recovered from the brucine salts has a 10-20\% higher S content and a 30-50\% stronger anticoagulant activity than the material submitted to electrodialysis. This could not be if the starting material had been a uniform product, which suffered partial destruction during electrodialysis, thus giving rise to new, less active fractions with lower $S$ content.

\section{The composition of the strongest heparin samples}

The composition of the strongest heparin samples obtained after removal of the brucine from the insoluble fractions of the brucine salt is of particular interest in relation to the crystalline heparin problem. In this way, $\mathrm{Na}$ salts of heparin from ox liver can be obtained with steadily increasing $S$ content; the compositions and anticoagulant activities of a series of such samples are given in Table 4.

Table 4. Compositions and anticoagulant activities of heparin fractions with high $S$ content

\begin{tabular}{|c|c|c|c|c|c|c|}
\hline \multirow[b]{2}{*}{ No. } & \multirow[b]{2}{*}{ g. } & \multirow{2}{*}{$\begin{array}{c}\text { Moisture } \\
\%\end{array}$} & \multicolumn{3}{|c|}{$\%$ of dry substance } & \multirow{2}{*}{$\begin{array}{l}\text { Anticoagulant activity of } \\
\text { the dry substance in \% of } \\
\text { standard (dry substance) }\end{array}$} \\
\hline & & & $\mathbf{S}$ & $\mathrm{Ca}$ & $\mathrm{Na}$ & \\
\hline 1. Na salt & 0.260 & $13 \cdot 0$ & $11 \cdot 73$ & - & - & 125 \\
\hline 2. Na salt & $0 \cdot 600$ & $9 \cdot 9$ & $12 \cdot 00$ & 一 & - & $125-130$ \\
\hline 3. Na salt & 0.240 & $12 \cdot 5$ & $12 \cdot 10$ & - & - & $125-130$ \\
\hline 4. Na salt & 0.770 & $17 \cdot 4$ & 12.5 & - & - & $135-145$ \\
\hline 5. Ca salt & $2 \cdot 00$ & $10 \cdot 6$ & $12 \cdot 56$ & $12 \cdot 60$ & - & $135-140$ \\
\hline 6. $\mathrm{Na}$ salt & 0.775 & $6 \cdot 7$ & $12 \cdot 90$ & - & 一 & $140-145$ \\
\hline 7. Ca salt & $0 \cdot 294$ & $12 \cdot 85$ & $13 \cdot 2$ & $12 \cdot 60$ & - & 153. \\
\hline 8. Na salt & $0 \cdot 650$ & $17 \cdot 5$ & $13 \cdot 8$ & - & $10 \cdot 43$ & 160 \\
\hline
\end{tabular}

The brucine salt of the liver heparin with the lowest solubility obtained in one experiment (sample 8 ) showed an exceptionally high content of S, i.e. about $14 \%$ of the dry $\mathrm{Na}$ salt. In fact, it had been obtained from a preparation of the crude heparin which showed an unusually strong activity, $125 \%$ of the standard powder. This salt, $0.650 \mathrm{~g}$., was analysed on four different occasions. The air-dry substance yielded 11.54 (11.48, $11.57) \% \mathrm{~S}$ corresponding to $14.0 \%$ of the dry substance (17.5\% moisture). On another occasion $13.7 \%(13.8,13.55)$ were obtained on analysing the dry substance $\left(100^{\circ}\right.$ in vacuo over $\mathrm{P}_{2} \mathrm{O}_{5}$ ). The ash content of the dry substance was $38.1 \% ; \mathrm{Na}, 10 \cdot 43 \%$.

This sample also showed a somewhat stronger biological activity than the other samples, about $160(160,160,150) \%$. The figures given were found in assays on three different days.

The $\mathrm{S}$ content of this sample equals or is slightly higher than the theoretical figure calculated for a mucoitin trisulphuric acid. Taking into account the fact that the substance is amorphous and certainly contains traces of foreign substances including salts, this figure might indicate admixture with a trace of a tetrasulphuric acid. So far, however, no conclusive proof could be obtained for the occurrence of such an acid in heparin. The analysis of this sample in any case disproves the earlier claims that pure heparin contains $2 \frac{1}{2}$ sulphate groups to each mucoitin unit, as do also the figures given by Jaques for the $\mathrm{S}$ content of the $\mathrm{Ba}$ salts of lung heparins from different animals.

\section{The polysaccharide fractions with lower $S$ content}

As to the nature of the remainder of the heparin polysaccharide after removal of the most active fractions, it would be of interest to know whether they have a similar organic skeleton. Particularly in lung heparin, one might expect the occurrence of a considerable 
- amount of chondroitin sulphuric acid originating from the cartilage of the bronchi. A sample of lung heparin was therefore fractionated as Ba salt. One fraction separated when $\mathrm{BaCl}_{2}$ was added at neutral reaction (I), another after the addition of $\mathrm{Ba}(\mathrm{OH})_{2}$ (II). The mother liquor was precipitated with alcohol and the precipitate dialysed in a cellophane sac against water. An insoluble fraction (III) was separated. The dialysed solution was concentrated to a small volume and $\mathrm{Ba}(\mathrm{OH})_{2}$ added until no further precipitate formed (IV). To the mother liquor, alcohol was added (precipitate V). The Ba salts were transformed into Na salts and then analysed (Table 5).

\begin{tabular}{|c|c|c|c|c|c|c|c|c|}
\hline \multirow{2}{*}{\multicolumn{2}{|c|}{ g. }} & \multirow[b]{2}{*}{$\begin{array}{c}\text { Moisture } \\
\%\end{array}$} & \multicolumn{5}{|c|}{$\%$ of dry substance } & \multirow{2}{*}{$\begin{array}{c}\text { Heparin activity of } \\
\text { air-dry substance } \\
\%\end{array}$} \\
\hline & & & Ash & Nitrogen & Sulphur & $\begin{array}{l}\text { Uronic } \\
\text { acid }\end{array}$ & $\underset{\text { sugar }}{\text { Amino- }}$ & \\
\hline I & $6 \cdot 5$ & $10 \cdot 0$ & 41 & $2 \cdot 45$ & $11 \cdot 0$ & $19 \cdot 5$ & 14 & 100 \\
\hline II & $1 \cdot 3$ & $11 \cdot 0$ & - & 2.9 & $6 \cdot 2$ & - & - & 15 \\
\hline III & $2 \cdot 7$ & $10 \cdot 5$ & 39 & $\mathbf{3} \cdot \mathbf{3}$ & $7 \cdot \overline{2}$ & 21 & $14 \cdot 5$ & 15 \\
\hline IV & $1 \cdot 15$ & $7 \cdot 1$ & - & 2.95 & $4 \cdot \overline{8}$ & - & - & - \\
\hline V & $4 \cdot 35$ & 10.9 & 37 & $2 \cdot 55$ & 0 & 22 & 17 & Nil \\
\hline
\end{tabular}

As is evident from Table 5, all fractions have a similar composition. They are all built up of an acetylated hexosamine and a hexuronic acid. A considerable part of the polysaccharide from the lungs is sulphur-free, and lacks heparin activity.

\section{The stability of heparin during autolysis, tryptic digestion and alkaline extraction}

The first stage at which destruction of heparin could take place is during the autolysis of the organs. In fact, Charles \& Scott [1933] found autolysis to be favourable for the preparation of heparin. The recent findings of Jaques [1940,2], that liver contains a heparinase capable of splitting heparin, indicate possible partial destruction of heparin during autolysis. The experience hitherto gained, however, indicates that no such destruction occurs. I have made repeated experiments, using both fresh and autolysed liver and lungs of cattle, and dog liver, and have found the same activity and the same S content of the heparin from one and the same source irrespective of whether it was extracted before or after autolysis for $36 \mathrm{hr}$.

There is not much reason, either, to assume a destruction of heparin during the digestion with the pancreatic extract, already recommended by Howell and applied by Charles $\&$ Scott in their routine method. However, this phase in the process of preparation was also controlled. It was found to be completely harmless.

To the trypsin solution used in the preparation of heparin a $\mathrm{Na}$ salt of heparin was added, $7.6 \mathrm{mg} . / \mathrm{ml}$. in one experiment and $0.75 \mathrm{mg}$. in another. The reaction was made slightly alkaline to litmus, toluene was added and the samples digested at $37^{\circ}$ for 4 days. In both samples the activity after digestion, as compared with the original strength, was still $100 \%$. The addition of $20 \mathrm{ml}$ of $N \mathrm{HCl}$ and $2 \mathrm{ml}$. of a $10 \% \mathrm{BaCl}_{2}$ solution to $20 \mathrm{ml}$. of the former sample did not cause any detectable precipitation of $\mathrm{BaSO}_{4}$, a fact which indicates that no sulphuric acid had been set free during the digestion.

If there is any possibility at all of destroying the heparin, it might be during the first stage of its preparation, i.e. during the alkaline extraction or the acidification with $\mathrm{H}_{2} \mathrm{SO}_{4}$ : If the amounts of $\mathrm{NaOH}$ and of $\left(\mathrm{NH}_{4}\right)_{2} \mathrm{SO}_{4}$ are properly balanced, as recommended by Charles and Scott, to give a $p \mathrm{H}$ of 9.4-9.1 in the mixture, no destruction seems to take place, as is evident from the following experiment.

$1 \mathrm{~g}$. of heparin of standard potency $(10.96 \% \mathrm{~S})$ was dissolved in a mixture of $30 \mathrm{ml}$.

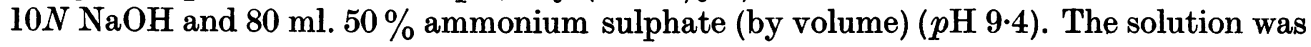


kept at $40^{\circ}$ for $1 \mathrm{hr}$., and at $85-90^{\circ}$ for $1 \mathrm{hr}$. more. The solution was then diluted with water and the heparin precipitated with alcohol. Free sulphates were removed by dialysis. $\mathrm{S}$ content of the heparin recovered, $11 \cdot 01 \%$. Heparin activity, 100 (possibly 95) \% of the standard. No destruction whatsoever had occurred.

Attention was also paid to the question of a possible destruction of heparin by the $\mathrm{H}_{2} \mathrm{SO}_{4}$ added to the first extract. Not even at this stage of the preparation could any decrease in heparin activity be traced.

\section{METHODS}

Amino-sugar. The quantitative determination of the amino-sugar content of the heparin preparations presents several difficulties. At first, the amino-sugar is only slowly liberated, boiling with conc. $\mathrm{HCl}$ for several hours being necessary for hydrolysis of the disaccharide [Jorpes \& Bergström, 1937]; furthermore, the free amino-sugar, glucosamine, is partly destroyed during this hydrolysis. Thus, it was found that of the glucosamine $10 \%$ was destroyed in $1 \mathrm{hr}$., $15 \%$ in $3 \mathrm{hr}$., and about $30 \%$ in $6 \mathrm{hr}$., if boiled in a water bath with conc. $\mathrm{HCl}$.

Glucosamine and galactosamine are known to give the same colour intensity in the Elson-Morgan reaction [Smyth et al. 1937], but in disaccharide units the linkage influences the colour formation. An accurate figure for the amino-sugar content therefore cannot be obtained. It was also observed that lower figures were consistently. obtained, if the hydrolysis lasted for some hours. The heparin preparations were therefore hydrolysed for only $30 \mathrm{~min}$., or $1 \mathrm{hr}$.

If material was available, $50 \mathrm{mg}$. were hydrolysed in a water bath in conc. $\mathrm{HCl}$ for $30 \mathrm{~min}$. The $\mathrm{HCl}$ was distilled off, the solution cautiously neutralized and the volume adjusted to $10 \mathrm{ml}$.; $0.25 \mathrm{ml}$. of this solution and of its dilutions $1: 1.5$ and $1: 2$ were taken for analysis. The different modifications of the Elson-Morgan method [Nilsson, 1936; Boyer \& Fürth, 1935; Smyth et al. 1937; Sörensen, 1938; Hewitt, 1938] were tried; the following technique was preferred.

A series of $10 \mathrm{ml}$. pyrex test-tubes marked at $5 \mathrm{ml}$. are used. To $0.25 \mathrm{ml}$. of the test solution, containing 0.4-1 mg. of the hydrochloride of the amino-sugar per ml., is added $0.2 \mathrm{ml}$. of $\mathrm{N} \mathrm{Na}_{2} \mathrm{CO}_{3}$ containing $1 \mathrm{ml}$. acetylacetone in $25 \mathrm{ml}$. The test tubes are boiled in a water bath for $15 \mathrm{~min}$. After cooling at room temperature for $1 \mathrm{hr}$., $2.5 \mathrm{ml}$. of glacial acetic acid are added to each tube of the series and then $0.25 \mathrm{ml}$. of the Ehrlich reagent. The tubes are boiled in a water bath for $10 \mathrm{~min}$. Glacial acetic acid is filled up to $5 \mathrm{ml}$. After mixing with a glass rod and keeping for $20 \mathrm{~min}$. the colour intensity is read through filter S53 of the step photometer using $1 \mathrm{~cm}$. cells.

Usually three different concentrations of an unknown solution are analysed simultaneously, all of them in duplicate. The sugar concentration is read off from a curve on semi-logarithmic paper obtained by analysing in duplicate four different concentrations of a known glucosamine solution. Such a curve is determined every time a series is boiled. Three different unknown samples can be analysed simultaneously, making a total of 26 test tubes in the series.

Sulphur: For the S analyses, 25-40 mg. of the material were fused with carbonatenitrate. The precipitate of $\mathrm{BaSO}_{4}$ was collected in a Neubauer-Gooch platinum iridium crucible, washed, ignited and washed again with dil. $\mathrm{HCl}$, ignited and weighed. Each analysis was made in duplicate or triplicate.

Anticoagulant activity. The anticoagulant activity was determined by the method described by Jorpes [1935, 2] and by Wilander [1938, p. 58]. Fresh ox blood taken direct from the vessel at the slaughterhouse was quickly decanted into a series of small test tubes, each containing $0.2 \mathrm{ml}$. of a dilute heparin solution. Five tubes in a stand contain standard heparin, $0.2 \mathrm{ml}$. each of a solution with $10,5,2.5,1.25$ and $0.63 \mathrm{mg}$. air-dry standard heparin in $32 \mathrm{ml}$. of physiological saline. The remaining five tubes of the same 
stand contain the unknown sample in the corresponding dilutions. Readings are made at room temperature after $1 \frac{1}{2}, 3,5,8$ and $12 \mathrm{hr}$., possibly also after $24 \mathrm{hr}$. Care must be taken that no air enters the test tubes and that the two parts of the stand, the cover and the bed, are tightly clamped together.

A difference in strength of $10 \%$ can be distinguished by this method. The figures of the anticoagulant activity of the heparin preparations given in Table 4 are therefore correct within 5-10\%. They were first determined in one or two series, each comprising 9 stands. Five of these samples, nos. 1, 2, 4, 5 and 6 , were assayed once more as air-dry powder against the air-dry standard heparin. The potency of four of the samples did not deviate more than possibly $5 \%$ from the strength found during the preliminary assaying. One of them only (no. 4) showed a 5-10\% greater potency than that found on the first day.

\section{Heparin standard}

The principles of expression of the anticoagulant activity of heparin, which have been applied by different workers, are almost as many as the authors themselves. Charles \& Scott [1933] elaborated in detail the method of determining the cat unit, originally suggested by Howell. One unit was the amount of anticoagulant which prevented coagulation of $1 \mathrm{ml}$. of cat blood kept for $24 \mathrm{hr}$. at $0^{\circ} ; 1 \mathrm{mg}$. of pure heparin contained about 500 units.

A few years later, Best \& Murray [1938] suggested that this unit should be replaced by another which corresponded to $0.01 \mathrm{mg}$. of pure heparin, assumed to be crystalline.

Other units have been recommended by Schmitz [1935], Chargaff et al. [1936], de Puoz [1938], Reinert \& Winterstein [1939], Astrup [1938], and by Jores of Promonta in Hamburg.

Schmitz suggested as a unit the amount of heparin, of which $\frac{1}{30}$ doubled the logarithm of the coagulation time in $0 \cdot 1 \mathrm{ml}$. of plasma. Chargaff et al. used hen's plasma and a muscle kinase of standard potency as suggested by Fischer \& Schmitz [1932]. They defined an inhibitor unit which was very small, $\frac{1}{15}$ of the original.Hotwell unit.

De Puoz, and Reinert \& Winterstein of the Hoffman-La Roche laboratory expressed the potency of the heparin in anticoagulant units (A.C.U.). One A.C.U. keeps $1 \mathrm{ml}$. of recalcified citrated plasma of cattle uncoagulated at $37^{\circ}$ for $4 \mathrm{hr}$. The necessary amount of Ca was to be titrated on each plasma specimen separately; $1 \mathrm{mg}$. of their pure product contained 500 A.C.U.

Realizing the complete impossibility of defining with accuracy an anticoagulant unit in terms of its action in some coagulation system, Bergström et al. [1937] tried to avoid all kinds of units by expressing the anticoagulant activity in mg. of a standard heparin; for this purpose, the protein-free heparin polysaccharide of ox liver was selected.

This principle has been found very convenient. The samples of ox liver heparin have an activity which is constant within about $10 \%$. The strength of the standard powder is about $65 \%$ of that of the strongest heparin available, the mucoitin trisulphuric acid from ox liver, presumably corresponding to the 'crystalline' heparin of Best and Murray which, according to them, contains 100 units per $\mathrm{mg}$. In the Swedish clinical records, therefore, the amount of anticoagulant given has been expressed in $\mathrm{mg}$. of the commercial heparin.

Because of differences in their mode of action [Astrup \& Fischer, 1938; Dam \& Glavind, 1939], no synthetic anticoagulants can replace the heparin as standard substance.

\section{Discussion AND SUMMARY}

The protein-free polysaccharide carrying heparin activity is quite different if prepared from different organs. The organic skeleton seems to be the same, namely, an acetylated amino-sugar combined with a hexuronic acid. The preparations differ in $\mathbf{S}$ content and anticoagulant activity, the liver heparins being the most active. The preparations are all 
inhomogeneous. From all of them, fractions with a higher $\mathrm{S}$ content can be isolated either as $\mathrm{Ba}$ or as brucine salts.

It is of particular interest to know whether these fractions with varying $S$ content really occur in the living animal or if they are secondary degradation products arising during the process of preparation. The former alternative is the most probable, because the heparin with the highest $\mathbf{S}$ content is very resistant. It is stable enough to resist both autolysis of the organs and tryptic digestion, and also alkaline extraction with subsequent acidification; it will therefore hardly give rise to any considerable amount of fractions with lower $\mathrm{S}$ content.

These polysaccharide fractions with lower $\mathbf{S}$ content also possess a certain anticoagulant activity. The biological activity is probably not due to admixture with the more active mucoitin trisulphuric acid, because the fractions are obtained from the mother liquors after removal of the less soluble brucine or Ba salts of the trisulphuric acid. The possibility, however, that the more soluble salts influence the solubility in water of the less soluble salts of the trisulphuric acid is not excluded. It seems as if all these different fractions carry an anticoagulant activity of their own, rapidly decreasing with decreasing $S$ content.

The recent findings of Jaques, that there is a species specificity, also add further evidence on this point. Heparin from dog liver is 2.5 times more active than ox liver . heparin with the same. S content. Taking into account also the fact that heparins with about the same $\mathrm{S}$ content originating from different organs show different anticoagulating effects, the liver heparins being the strongest, heparin cannot be considered to be a homogeneous compound in the same sense as the other crystalline hormones, such as insulin.

In order to explain the exceptionally high biological activity of dog heparin, an attempt was made at isolating a tetrasulphuric acid as brucine salt from dog liver heparin. No fraction with a higher $\mathrm{S}$ content than that of the trisulphuric acid could, however, be obtained.

Whilst the fact still remains, that the exceptionally strong electric charge and the molecular configuration are the most outstanding properties of the heparin polysaccharide, it must be admitted that we actually know very little about the ultimate underlying principle causing the anticoagulating activity.

This investigation has been aided by grants from the Rockefeller Foundation and from the Therese and Johan Andersson Memorial Foundation.

\section{REFERENCES}

Astrup, T. [1938]. Enzymologia, 5, 12.

Astrup, T. \& Fischer, A. [1938]. Proc. Soc. exp. Biol., N.Y., 38, 494.

Bergström, S., Jorpes, E. \& Wilander, O. [1937]. Skand. Arch. Physiol. 76, 175.

Best, C. H. \& Murray, D. N. G. [1938]. J. Amer. med. Ass. 110, 118.

Boyer, R. \& Fürth, O. [1935]. Biochem. Z. 282, 242.

Chargaff, E., Bancroft, F. W. \& Stanley-Brown, M. [1936]. J. biol. Chem. 115, 149, 155.

Charles, A. F. \& Scott, D. A. [1933]. J. biol. Chem. 102, 425, 437.

[1936]. Biochem. J. 30, 1927.

Charles, A. F. \& Todd, A. R. [1940]. Biochem. J. 34, 112.

Dam, H. \& Glavind, J. [1939]. Skand. Arch. Physiol. 82, 221.

Fischer, A. \& Schmitz, A. [1932]. Hoppe-Seyl Z. 210, 129. [1933]. Hoppe-Seyl Z. 216, 264, 274.

Hewitt, L. F. [1938]. Biochem. J. 32, 1554.

Howell, W. H. [1928]. Bull. Johns Hopk. Hosp. 42, 199.

Jaques, L. B. [1940, 1]. Science, 92, 488.

$-[1940,2]$. J. biol. Chem. 133, 445. 
Jaques, L. B. \& Waters, E. T. [1940]. Amer. J. Physiol. 129, P 389.

Jorpes, E. [1935, 1]. Naturwissenschaften, 23, 196.

$-11935,2]$. Biochem. J. 29, 1817.

Jorpes, E. \& Bergström, S. [1936]. Hoppe-Seyl Z. 244, 253.

- [1937]. J. biol. Chem. 118, 447.

Meyer, K. [1938]. Cold Spr. Harb. Symp. Quant. Biol. 6, 97.

Nilsson, 'I. [1936]. Biochem. Z. 285, 386.

de Puoz, J. [1938]. Schweiz. med. Wschr. 68, 524.

Reinert, M. \& Winterstein, A. [1939]. Arch. int. Pharmacodyn. 62, 47.

Schmitz, A. [1935]. Hoppe-Seyl Z. 234, 216.

Smyth, E. M., Palmer, J. W. \& Meyer, K. [1937]. J. biol. Chem. 119, 491.

Sorensen, M. [1938]. C.R. Lab. Carlsberg, 22, 487.

Wilander, O. [1938]. Skand. Arch. Physiol. 81, Suppl. 15. 